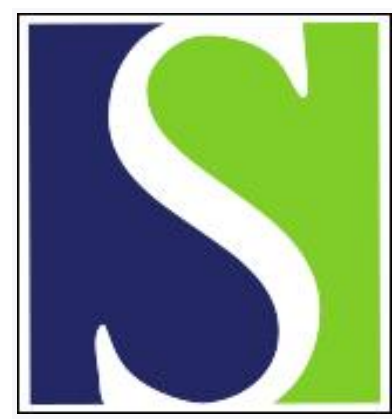

Scand J Work Environ Health 2008;34(4):307-315

https://doi.org/10.5271/sjweh.1271

Published online: 22 Sep 2008, Issue date: Aug 2008

Impact of retirement on risky driving behavior and attitudes towards road safety among a large cohort of French drivers (the GAZEL cohort)

by Bhatti JA, Constant A, Salmi L-R, Chiron M, Lafont S, Zins M, Lagarde $\mathrm{E}$

Affiliation: Equipe Avenir "Prévention et Prise en Charge des Traumatismes", INSERM U897, Université Victor Segalen Bordeaux 2, Case 11, 146 Rue Léo Saignât, 33076 Bordeaux Cedex, France. junaid.bhatti@yahoo.com

Key terms: attitude; cell phone; cell phone use; driver; driving; France; GAZEL cohort; professional activity; retirement; risky driving behavior; road safety; road traffic safety; sleepy driving; speedy driving; traffic

This article in PubMed: www.ncbi.nlm.nih.gov/pubmed/18815717 


\title{
Impact of retirement on risky driving behavior and attitudes towards road safety among a large cohort of French drivers (the GAZEL cohort)
}

\author{
by Junaid A Bhatti, MSc, ${ }^{1}$ Aymery Constant, PhD, ${ }^{1}$ L-Rachid Salmi, PhD, ${ }^{1,2}$ Mireille Chiron, PhD, ${ }^{3}$ Sylvi- \\ ane Lafont, PhD, ${ }^{3}$ Marie Zins, MD, ${ }^{4}$ Emmanuel Lagarde, PhD ${ }^{1}$
}

\begin{abstract}
Bhatti JA, Constant A, Salmi L-R, Chiron M, Lafont S, Zins M, Lagarde E. Impact of retirement on risky driving behavior and attitudes towards road safety among a large cohort of French drivers (the GAZEL cohort). Scand $J$ Work Environ Health 2008;34(4):307-315.
\end{abstract}

\begin{abstract}
Objectives This study investigated changes in driving behavior and attitudes towards road safety, following retirement, in a large cohort of road users.

Methods In 2001, 14226 participants of the GAZEL cohort in France reported their attitudes towards road safety and driving behavior using a self-administered driving behavior and road safety questionnaire. In 2004, $82 \%$ of the group ( $\mathrm{N}=11706)$ responded to the same questionnaire. Two complementary logistic regression analyses were performed to assess the association of (i) retirement with change in safe driving behavior and attitudes towards road safety between 2001 and 2004 and (ii) time since retirement with risky driving behavior and negative attitudes towards road safety in 2001.

Results Among the participants who were active in 2001 (N=3927), those retiring between 2001 and 2004 $(66 \%)$ were more likely to have discontinued sleepy driving [adjusted odds ratio $(\mathrm{aOR}) 2.12, \mathrm{P}<0.001$ ] and phone use while driving (aOR 1.74, $\mathrm{P}=0.006$ ) than those who remained professionally active. The second analysis showed that the likelihood of sleepy driving and phone use while driving decreased soon after retirement, whereas that of speedy driving decreased over a longer interval. Retirement had no influence on driving while intoxicated or attitudes towards road safety.

Conclusions The results suggest that any professional activity may account for some risky road behavior. As work-related road traffic accidents are responsible for one out of every four road casualties in France, the monitoring and prevention of sleepy driving and phoning while driving among workers should be further considered.
\end{abstract}

Key terms cell phone use; professional activity; road traffic safety; sleepy driving; speedy driving.

Driving behavior has been recognized as the principal cause of road traffic accidents (1), but its relationship to the work environment among nonprofessional drivers has been studied very little (2-4). There is evidence that professional factors may play a role in the risk of being involved in a crash, since road traffic accidents are a leading cause of deaths at work in industrialized countries (5-7). In France, work-related road traffic accidents are responsible for one road traffic casualty out of every four $(6,8)$, and $40 \%$ of fatal work accidents are road traffic accidents, a proportion that increases to $60 \%$ when accidents during commuting to and from work are included (9).

Many studies show that professional drivers, such as taxi or truck drivers, have a higher risk of accident involvement than the general population, mainly because

1 Equipe Avenir "Prévention et Prise en Charge des Traumatismes", Centre de Recherche "Epidémiologie et Biostatistique”, Institut Nationale de la Santé et de la Recherche Médicale Unité 897 (INSERM U897), Institut de Santé Publique, d'Epidémiologie et de Développement (ISPED), Université Victor Segalen Bordeaux, Bordeaux, France.

2 Service d'information médicale, CHU de Bordeaux, Bordeaux, France.

3 Unité Mixte de Recherche et Surveillance Transport Travail Environnement (UMRESTTE, UMR T9405), Institut National de Recherche sur les Transports et leur Sécurité (INRETS), Bron, Université de Lyon, Lyon; Institut de Veille Sanitaire, Saint-Maurice, Farnce.

4 Equipe "Risques post-professionnels-Cohortes", Institut Nationale de la Santé et de la Recherche Médicale Unité 687 (U687), Saint Maurice, France.

Correspondence to: JA Bhatti, Equipe Avenir "Prévention et Prise en Charge des Traumatismes", Institut National de la Santé et de la Recherche Médicale Unité 897 (INSERM U897), Université Victor Segalen Bordeaux 2, Case 11, 146 Rue Léo Saignât, 33076 Bordeaux Cedex, France. [E-mail: junaid.bhatti@yahoo.com] 
of their high amount of driving mileage $(2,10,11)$. Although driving exposure is undoubtedly related to work-related fatalities on the road, other work-related factors may increase the risk of road traffic accidents, among both professional and nonprofessional drivers (12). Work pressure, responsibilities, and work constraints are likely to affect a person's ability to drive during and outside workhours (3). For instance, we have shown that work-related fatigue, shift work, and prolonged standing postures at work were significant risk factors for road traffic accidents in a large cohort of employees (13).

Accordingly, moving out from under the strain of work may have a significant impact on driving behavior. Data from a 1-year prospective randomized trial with 224 men showed a decrease in the magnitude of type-A personality, characterized by impatience, hostility, and aggressiveness, after 1 year of normal retirement, suggesting that people are more patient, easy-going, and relaxed after they relinquish their work constraints (14). As aggressiveness and type-A personality are significantly related to more road traffic accidents, a greater frequency of broken traffic laws, greater impatience when driving, more risky driving behavior, and negative attitudes towards road traffic safety (15), such changes after normal retirement may improve road behavior and attitudes towards traffic safety. Unfortunately, studies on the road behavior of older drivers are cross-sectional, and therefore it is difficult to distinguish between changes in driving that reflect natural adjustment to a changed life situation and those reflecting age- or health-related issues, such as impaired ability to drive or dementia $(16,17)$.

Similarly, recent findings suggest that age plays a major role in attitudes towards road traffic safety, as older drivers have higher levels of normative motivation to comply with traffic laws than younger drivers do (18), but the influence of work discontinuation alone on attitudes towards road traffic safety has not yet been studied. Previous research, however, has shown the importance of knowledge, beliefs, and attitudes in determining behavior, and changing attitudes towards road traffic safety is considered an effective and longlasting approach with which to improve road behavior (19).

As normal retirement represents a relinquishing of demanding or stressful career jobs, work pressures, responsibilities, and work constraints (20), prospectively assessing behavioral and attitudinal changes after this major life change represents an opportunity to evaluate the influence of professional activity on road traffic accidents. The objective of this longitudinal study was to investigate changes in driving behavior and attitudes towards road safety after normal retirement in a large cohort of road users in diverse professional trades.

\section{Study population and methods}

\section{Study population}

The participants were current employees or recent retirees of the French national electricity and gas companies, Electricité De France-Gaz De France (EDF-GDF), who volunteered to participate in a research cohort, known as the GAZEL cohort (GAZEL stands for GAZ and ELectricité) (21). This cohort was established in 1989 and originally included 20624 persons working at EDFGDF, men aged $40-50$ years $(\mathrm{N}=15010)$ and women aged $35-50$ years $(\mathrm{N}=5$ 614) at baseline. Since 1989, this cohort has been followed by means of yearly selfadministered questionnaires and data collection from the company's human resources and medical departments. The objectives and methods of the cohort have been described in detail elsewhere (21).

A questionnaire on driving behavior and road safety was administered twice, in February 2001 and February 2004. The drivers who participated in the first survey received the second one in 2004. This questionnaire was previously pilot-tested on 500 randomly selected participants. The answers and comments of the 330 respondents were used to finalize the questionnaire used in this study.

The study protocol was approved by the French data protection authority, the Commission Nationale Informatique et Liberté (CNIL).

\section{Measurements}

The exact date of retirement was available for all of the participants who retired before September 2005. Behavioral data included maximum speed reported on three types of roads (roads in built-up areas, rural roads, and highways), driving while intoxicated, sleepy driving, and cell phone use while driving. Risky behavior, which was significantly associated with the risk of being involved in an accident, was defined in a previous study (22) using the same cohort database (ie, risky speedy driving was defined as reporting a maximum speed over $65 \mathrm{~km} / \mathrm{hour}$ in built-up areas, $100 \mathrm{~km} / \mathrm{hour}$ on rural roads and $145 \mathrm{~km} /$ hour on highways, driving while intoxicated was defined as reported driving after having taken too much alcohol to drive a "few times a year or more" during the past 12 months, risky sleepy driving was defined as reported driving while feeling sleepy a "few times a year or more" during the past 12 months, and risky phone use while driving was defined as initiating a cellular telephone call while driving, whatever the circumstances).

Attitudes towards traffic safety were assessed by asking the participants whether they agreed or disagreed with a set of 12 statements, referring to two topics with 
six statements each, related to traffic safety and currently debated in France, namely, relaxing existing regulations and increased traffic enforcement. These statements have been described in detail elsewhere (23). The level of agreement was assessed by summing up the number of affirmations with each topic in a summary score (range 0-6). Agreement with relaxing existing regulations was categorized in two approximately equivalent categories, low (range 0-1) and high (range 2-6). Similarly, agreement with increased traffic enforcement was categorized into the following two groups: low (range 0-3) and high (range 4-6). A "negative attitude" towards road traffic safety was defined as high agreement with relaxing existing regulations and as low agreement with increased traffic enforcement.

Sociodemographic data from the cohort database included gender, year of birth, marital status, occupational category, and alcohol consumption. Light drinkers of alcohol were defined as men or women reporting 1-14 or 1-7 drinks, respectively, over 1 week, as opposed to heavy drinkers (men or women reporting $>14$ or $>7$ drinks, respectively) over the same period. Regular drinkers were defined as those who reported consuming alcohol on 3 days in the week, as opposed to episodic drinkers who reported drinking alcohol on $<3$ days a week. Other potential factors included in the study were annual driving mileage during the last 12 months and type of vehicle owned in 2001.

\section{Analyses}

Risk behavior and negative attitudes towards road safety were assessed in 2001 and 2004, and the percentages of change were computed for each variable (statistical significance assessed using the McNemar test). Safe behavioral change was defined as a discontinuation of a given risk behavior in 2004 among those who reported it in 2001, and, conversely, risky behavioral change was defined as discontinuation of a given safe behavior in 2004 among those who reported it in 2001. Safe attitudinal change was defined as reporting a positive attitude towards road traffic safety in 2004 among those who reported a negative attitude in 2001, and, conversely, risk attitudinal change was defined as reporting a negative attitude towards road traffic safety in 2004 among those who reported a positive attitude in 2001. A first analysis prospectively assessed the relationship between retirement and safe changes between 2001 and 2004 among the participants who were still professionally active in 2001. The likelihood of the given safe behavioral or attitudinal change was assessed among the participants who retired between 2001 and 2004 as compared with those who remained professionally active in 2004, using an unconditional logistic regression model and SAS software, version 9.1.3 (24). These analyses were further adjusted for gender, age, marital status, alcohol consumption, occupational categories, road mobility, and type of vehicle owned in 2001.

A second analysis was conducted to assess how rapidly changes occurred following retirement by measuring the likelihood of risky behavior and attitudes towards road safety in 2001 as a function of time since retirement. The exact retirement date and the date of response to the 2001 questionnaire were used to obtain the time since retirement in 2001. The likelihood of risky behavior and negative attitudes towards road traffic safety among the professionally active participants in 2001 were compared with those of participants who had been retired for less than 2 years and those who had been retired for 2 to 3 years. Logistic regression analyses were performed with adjustment for the other variables as previously described.

\section{Results}

In 2001, the questionnaire was sent to 19894 living members of the cohort. The response rate was $71.5 \%$ $(\mathrm{N}=14$ 226). The response rate of the second driving behavior questionnaire, sent in 2004 to 13447 participants, was $87.1 \%(\mathrm{~N}=11706)$. The participants reporting that they did not drive any 2- or 4-wheel motorized vehicle $(\mathrm{N}=399)$ were excluded from the analysis. Questionnaires with improperly recorded response dates (day or month missing) were also excluded.

Changes in driving behavior or attitudes towards road safety among the retired and professionally active participants between 2001 and 2004

The participants who responded to the two questionnaires and were professionally active on the response date in $2001(\mathrm{~N}=3$ 927) were selected for this analysis. Altogether $66 \%$ of them retired between the 2001 and 2004 questionnaires [mean age at retirement: 55.7 (SD 2.2) years]. They were managers $(40.6 \%)$, skilled workers $(50.1 \%)$, and unskilled workers (9.3\%), and most of them were men $(65.8 \%)$. Alcohol consumption was considered to be "high" for $29.0 \%$ of the respondents and "low" for $56.9 \%$, while $14.1 \%$ reported no alcohol consumption (table 1). One-fourth reported driving a small vehicle with annual mileage from 10000 to $20000 \mathrm{~km} /$ year.

Between 2001 and 2004, the proportion of participants who changed to safe behavior was significantly higher than those who changed to risky behavior $(\mathrm{P}<0.05)$. For instance, $79.7 \%$ of the participants $(\mathrm{N}=1063)$ who reported risky speed in built-up areas in 2001 changed to safe speed in 2004 (table 2), while only $3.4 \%$ of the participants $(\mathrm{N}=2785)$ who reported safe speed in 2001 changed to risky speed on the same 
Table 1. Characteristics of the participants who were professionally active in 2001 and responded to the driving behavior questionnaire in 2001 and 2004-the GAZEL cohort ( $N=3$ 927).

\begin{tabular}{|c|c|c|c|c|c|c|}
\hline \multirow[t]{2}{*}{ Characteristic } & \multicolumn{2}{|c|}{ Retired } & \multicolumn{2}{|c|}{$\begin{array}{l}\text { Not retired } \\
(2001-2004)\end{array}$} & \multicolumn{2}{|c|}{ Total } \\
\hline & $\mathrm{N}$ & $\%$ & N & $\%$ & $\mathrm{~N}$ & $\%$ \\
\hline \multicolumn{7}{|l|}{ Gender and year of birth } \\
\hline \multicolumn{7}{|l|}{ Male } \\
\hline 1939-1943 & 244 & 6.2 & 2 & 0.1 & 246 & 6.3 \\
\hline $1944-1948$ & 1779 & 45.3 & 558 & 14.2 & 2337 & 59.5 \\
\hline \multicolumn{7}{|l|}{ Female } \\
\hline 1939-1943 & 74 & 1.9 & 0 & 0 & 74 & 1.9 \\
\hline $1944-1948$ & 323 & 8.2 & 149 & 3.8 & 472 & 12.0 \\
\hline $1949-1953$ & 170 & 4.3 & 628 & 16.0 & 798 & 20.3 \\
\hline \multicolumn{7}{|l|}{ Marital status a } \\
\hline $\begin{array}{l}\text { Single, divorced or } \\
\text { widow(er) }\end{array}$ & 293 & 7.6 & 281 & 7.3 & 574 & 14.9 \\
\hline Living with a partner & 2231 & 58.1 & 1039 & 27.0 & 3270 & 85.1 \\
\hline \multicolumn{7}{|c|}{ Socioprofessional categories ${ }^{a}$} \\
\hline Unskilled worker & 225 & 5.7 & 139 & 3.6 & 364 & 9.3 \\
\hline Skilled worker & 1288 & 32.8 & 679 & 17.3 & 1967 & 50.1 \\
\hline Manager & 1074 & 27.4 & 519 & 13.2 & 1593 & 40.6 \\
\hline \multicolumn{7}{|l|}{ Alcohol consumption ${ }^{a}$} \\
\hline None & 282 & 7.5 & 246 & 6.6 & 528 & 14.1 \\
\hline Low quantity episodic & 893 & 23.8 & 510 & 13.5 & 1403 & 37.3 \\
\hline Low quantity regular & 518 & 13.8 & 220 & 5.8 & 738 & 19.6 \\
\hline High quantity episodic & 8 & 0.2 & 15 & 0.4 & 23 & 0.6 \\
\hline High quantity regular & 769 & 20.5 & 296 & 7.9 & 1065 & 28.4 \\
\hline \multicolumn{7}{|l|}{ Type of vehicle ${ }^{a}$} \\
\hline Compact or economy & 1307 & 34.7 & 833 & 22.2 & 2140 & 56.9 \\
\hline Sedan or family & 1132 & 30.1 & 426 & 11.3 & 1558 & 41.4 \\
\hline Sport & 46 & 1.2 & 16 & 0.5 & 62 & 1.7 \\
\hline \multicolumn{7}{|l|}{ Mileage driven in $2001^{\text {a }}$} \\
\hline$<10000 \mathrm{~km}$ & 460 & 11.9 & 432 & 11.2 & 892 & 23.1 \\
\hline $10000-20000 \mathrm{~km}$ & 1212 & 31.5 & 594 & 15.4 & 1806 & 46.9 \\
\hline$>20000 \mathrm{~km}$ & 880 & 22.8 & 275 & 7.2 & 1155 & 30.0 \\
\hline
\end{tabular}

a Data are not available for all of the participants. road in 2004 (table 3). The same trend was observed for all of the considered types of risky behavior, except for driving while intoxicated, for which fewer participants changed to safe behavior $(\mathrm{N}=280)$ than to risky behavior $(\mathrm{N}=370)$. Similarly, the proportion of participants who changed to positive attitudes towards relaxing existing regulations was significantly higher than those who changed towards negative attitudes $(45.5 \%$ versus $12.3 \%)$. Similar proportions of participants changed to positive and negative attitudes towards increased traffic enforcement between 2001 and 2004.

Between 2001 and 2004, risky speeding decreased by $70.7 \%$ for built-up areas, by $53.1 \%$ for rural roads, and by $76.5 \%$ for highways $(\mathrm{P}<0.001)$. Similarly, sleepy driving decreased by $12.1 \%$, and phone use while driving decreased by $46.2 \%$, whereas driving while intoxicated increased by $10.7 \%$ over the same period $(\mathrm{P}<0.001)$. Similarly, the proportion of participants who agreed with relaxing existing regulations decreased by $28.1 \%$ $(\mathrm{P}<0.001)$, and those who changed to increased traffic enforcement increased by $4.4 \%(\mathrm{P}=0.01)$.

The participants who retired between 2001 and 2004 were more likely to discontinue risky sleepy driving and phone use while driving than the participants who remained professionally active (table 4). No significant association was found between other behavioral and attitudinal changes between 2001 and 2004 and retirement during the same period.

\section{Risky behavior or attitudes towards road safety among the retired and professionally active participants in 2001}

Out of the 8005 participants who were selected for this analysis, $41.3 \%$ were professionally active in 2001,

Table 2. Change in safe driving behavior and positive attitudes towards road safety observed between 2001 and 2004 among those who were professionally active in 2001 - the GAZEL cohort.

\begin{tabular}{|c|c|c|c|c|c|c|c|c|c|c|c|}
\hline \multirow[t]{3}{*}{ Behavior attribute } & \multirow{2}{*}{\multicolumn{2}{|c|}{$\begin{array}{l}\text { Risk beha- } \\
\text { vior or atti- } \\
\text { tudes in } 2001\end{array}$}} & \multicolumn{6}{|c|}{ Change in safe behavior or attitudes between 2001 and 2004} & \multirow{2}{*}{\multicolumn{2}{|c|}{$\begin{array}{l}\text { Risk beha- } \\
\text { vior or atti- } \\
\text { tudes in } 2004\end{array}$}} & \multirow{3}{*}{$\begin{array}{c}\text { Change } \\
\text { in risk } \\
\text { behavior } \\
(\%)\end{array}$} \\
\hline & & & \multicolumn{2}{|c|}{ Total } & \multicolumn{2}{|c|}{ Retired } & \multicolumn{2}{|c|}{ Not retired } & & & \\
\hline & $\mathrm{N}$ & $\%$ & $\mathrm{~N}$ & $\%$ & $\mathrm{~N}$ & $\%$ & $\mathrm{~N}$ & $\%$ & $\mathrm{~N}$ & $\%$ & \\
\hline Speed in built-up areas ${ }^{\text {a }}$ & 1063 & 27.6 & 847 & 79.7 & 584 & 54.9 & 263 & 24.8 & 311 & 8.1 & -70.7 \\
\hline Speed on rural roads ${ }^{a}$ & 1547 & 40.2 & 1057 & 68.3 & 743 & 48.0 & 314 & 20.3 & 726 & 18.9 & -53.1 \\
\hline Speed on highways a & 1060 & 27.7 & 880 & 83.0 & 620 & 58.5 & 260 & 24.5 & 249 & 6.5 & -76.5 \\
\hline Driving while intoxicated & 843 & 22.0 & 280 & 33.2 & 209 & 24.8 & 71 & 8.4 & 933 & 24.4 & +10.7 \\
\hline Sleepy driving & 1719 & 44.8 & 586 & 34.1 & 429 & 25.0 & 157 & 9.1 & 1512 & 39.4 & -12.1 \\
\hline Phone use while driving & 621 & 16.8 & 403 & 64.9 & 272 & 43.8 & 131 & 21.1 & 334 & 9.0 & -46.2 \\
\hline Relaxing existing regulations & 1477 & 41.3 & 673 & 45.5 & 460 & 31.1 & 213 & 14.4 & 1062 & 29.7 & -28.1 \\
\hline Increased traffic enforcement & 1709 & 48.2 & 414 & 24.2 & 282 & 16.5 & 132 & 7.7 & 1785 & 50.3 & +4.4 \\
\hline
\end{tabular}

a Excessive speed was defined as "> $65 \mathrm{~km} /$ hour" in built-up areas, "> $100 \mathrm{~km} / \mathrm{hour"} \mathrm{on} \mathrm{rural} \mathrm{roads,} \mathrm{and} \mathrm{">145} \mathrm{km/hour"} \mathrm{on} \mathrm{highways.}$ 
Table 3. Changes in risky driving behavior and negative attitudes towards road safety observed between 2001 and 2004 among those who were professionally active in 2001 - the GAZEL cohort.

\begin{tabular}{|c|c|c|c|c|c|c|c|c|c|c|c|}
\hline \multirow[t]{3}{*}{ Behavior attribute } & \multirow{2}{*}{\multicolumn{2}{|c|}{$\begin{array}{l}\text { Safe beha- } \\
\text { vior or atti- } \\
\text { tudes in } 2001\end{array}$}} & \multicolumn{6}{|c|}{ Change in risky behavior or attitudes between 2001 and 2004} & \multirow{2}{*}{\multicolumn{2}{|c|}{$\begin{array}{l}\text { Safe beha- } \\
\text { vior or atti- } \\
\text { tudes in } 2004\end{array}$}} & \multirow{3}{*}{$\begin{array}{c}\text { Change } \\
\text { in safe } \\
\text { behavior } \\
(\%)\end{array}$} \\
\hline & & & \multicolumn{2}{|c|}{ Total } & \multicolumn{2}{|c|}{ Retired } & \multicolumn{2}{|c|}{ Not retired } & & & \\
\hline & $\mathrm{N}$ & $\%$ & $\mathrm{~N}$ & $\%$ & $\mathrm{~N}$ & $\%$ & $\mathrm{~N}$ & $\%$ & $\mathrm{~N}$ & $\%$ & \\
\hline Speed in built-up areas ${ }^{a}$ & 2785 & 72.4 & 95 & 3.4 & 56 & 2.0 & 39 & 1.4 & 3537 & 91.9 & +27.0 \\
\hline Speed on rural roads a & 2299 & 59.8 & 236 & 10.3 & 148 & 6.5 & 88 & 3.8 & 3120 & 81.1 & +35.7 \\
\hline Speed on highways a & 2770 & 72.3 & 69 & 2.5 & 47 & 1.7 & 22 & 0.8 & 3581 & 93.5 & +29.3 \\
\hline Driving while intoxicated & 2988 & 78.0 & 370 & 12.3 & 259 & 8.6 & 111 & 3.7 & 2898 & 75.7 & -3.01 \\
\hline Sleepy driving & 2119 & 55.2 & 379 & 17.9 & 220 & 10.4 & 159 & 7.5 & 2326 & 60.6 & +9.8 \\
\hline Phone use while driving & 3073 & 83.2 & 116 & 3.8 & 55 & 1.7 & 61 & 1.9 & 3360 & 91.0 & +9.3 \\
\hline Relaxing existing regulations & 2100 & 58.7 & 258 & 12.3 & 160 & 7.6 & 98 & 4.7 & 2515 & 70.3 & +19.8 \\
\hline Increased traffic enforcement & 1838 & 51.8 & 490 & 26.7 & 312 & 17.0 & 178 & 9.7 & 1762 & 49.6 & -4.1 \\
\hline
\end{tabular}

a Excessive risky speed was defined as speed "> $>5 \mathrm{~km} /$ hour" in built-up areas, ">100 km/hour” on rural roads, and ">145 km/hour" on highways.

Table 4. Association between changes to safe driving behavior and positive attitudes towards road safety (outcome variable) between 2001 and 2004 and retirement over the same period (independent variable) in the GAZEL cohort-multivariate logistic regression models. (OR = odds ratio, $95 \% \mathrm{Cl}=95 \%$ confidence interval)

\begin{tabular}{|c|c|c|c|c|c|c|c|c|}
\hline \multirow[t]{2}{*}{ Outcome variables } & \multicolumn{4}{|c|}{ Crude models ${ }^{a}$} & \multicolumn{4}{|c|}{ Adjusted models ${ }^{b}$} \\
\hline & N & Odds ratio & $95 \% \mathrm{Cl}$ & P-value ${ }^{c}$ & $\mathrm{~N}$ & Odds ratio & $95 \% \mathrm{Cl}$ & P-value ${ }^{c}$ \\
\hline Speed in built-up areas ${ }^{d}$ & 1063 & 1.21 & $0.88-1.65$ & 0.24 & 975 & 1.27 & $0.86-1.87$ & 0.22 \\
\hline Speed on rural roads ${ }^{d}$ & 1547 & 1.18 & $0.94-1.48$ & 0.16 & 1414 & 1.22 & $0.92-1.63$ & 0.16 \\
\hline Speed on highways ${ }^{d}$ & 1060 & 1.16 & $0.82-1.64$ & 0.38 & 974 & 0.91 & $0.60-1.38$ & 0.65 \\
\hline Driving while intoxicated & 843 & 0.84 & $0.60-1.17$ & 0.30 & 768 & 0.92 & $0.62-1.37$ & 0.69 \\
\hline Sleepy driving & 1719 & 1.54 & $1.24-1.92$ & $<0.001$ & 1557 & 2.12 & $1.61-2.81$ & $<0.001$ \\
\hline Phone use while driving & 621 & 1.83 & $1.30-2.56$ & $<0.001$ & 564 & 1.74 & $1.17-2.61$ & 0.006 \\
\hline Relaxing existing regulations ${ }^{e}$ & 1477 & 0.96 & $0.77-1.19$ & 0.70 & 1318 & 1.07 & $0.82-1.41$ & 0.61 \\
\hline Increased traffic enforcement ${ }^{\mathrm{e}}$ & 1709 & 0.88 & $0.69-1.11$ & 0.28 & 1562 & 1.10 & $0.82-1.48$ & 0.53 \\
\hline
\end{tabular}

a Unadjusted odds ratio; retired 2001-2004 versus professionally active participants in 2004.

${ }^{\text {b }}$ Adjusted odds ratio; retired 2001-2004 versus professionally active participants in 2004, adjusted for gender, age (born 1938-1943 as reference, 19441948, and 1949-1953), marital status (living with partner and living alone), socioprofessional categories (unskilled workers as reference, skilled workers and managers), alcohol consumption (nonconsumers as reference, low quantity episodic, low quantity regular, and high quantity episodic and regular) vehicle category (compact or economy as reference, sedan or family, sports or jeep), and annual mileage (<10 $000 \mathrm{~km} / \mathrm{year}$ as reference, $10000-20000$ $\mathrm{km} / \mathrm{year}$, and $>20000 \mathrm{~km} / \mathrm{year})$.

c P-values were reported from the likelihood ratio tests for retirement status.

${ }^{d}$ Risky speed was defined as speed "> $>5 \mathrm{~km} / \mathrm{hour"} \mathrm{in} \mathrm{built-up} \mathrm{areas,} \mathrm{">100} \mathrm{km/hour"} \mathrm{on} \mathrm{rural} \mathrm{roads,} \mathrm{and} \mathrm{">}>145 \mathrm{~km} / \mathrm{hour"} \mathrm{on} \mathrm{highways.}$

${ }^{e}$ Odds ratio for change to positive attitude scores in 2004 among those who reported negative attitudes in 2001.

whereas $23.5 \%$ had been retired for less than 2 years, and $35.2 \%$ had been retired for 2 to 3 years [mean age at retirement: 54.3 (SD 2.6) years]. Most of them were men $(80.7 \%)$ and skilled workers $(52.3 \%)$.

The participants who had been retired for 2 to 3 years were more likely to report safer speed in built-up areas, on rural roads, and on highways than the professionally active participants (figure $1 \mathrm{~A}-\mathrm{C}$ ). Similarly, the likelihood of sleepy driving and phone use while driving was lower among the participants who had been retired for less than 2 years and those retired for 2 to 3 years than among the professionally active participants (figure 1 E-F). The likelihood of driving while intoxicated and negative attitudes towards road safety were similar among the groups (figure $1 \mathrm{D}, \mathrm{G}-\mathrm{H}$ ).

\section{Discussion}

Findings from this study of a large cohort of participants belonging to diverse trades show that the likelihood of risky types of road behavior, except driving while intoxicated, decreased between 2001 and 2004 among all of the participants and that retirement tended to facilitate changes towards safer road behavior. We showed that the likelihood of discontinuing sleepy driving and phone use while driving was significantly higher among the participants who retired between 2001 and 2004 than among those who remained professionally active. The analyses of the likelihood of risky road behavior as a function of time since retirement before 2001 highlighted the fact that the likelihood of sleepy driving and phone use 
A) Speed in built-up areas

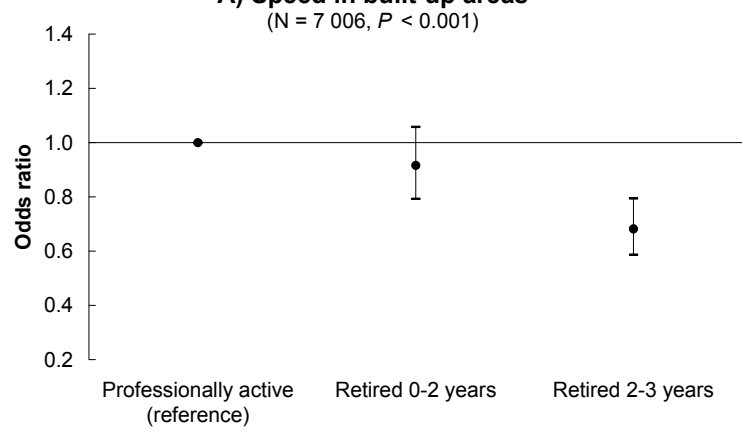

C) Speed on highways

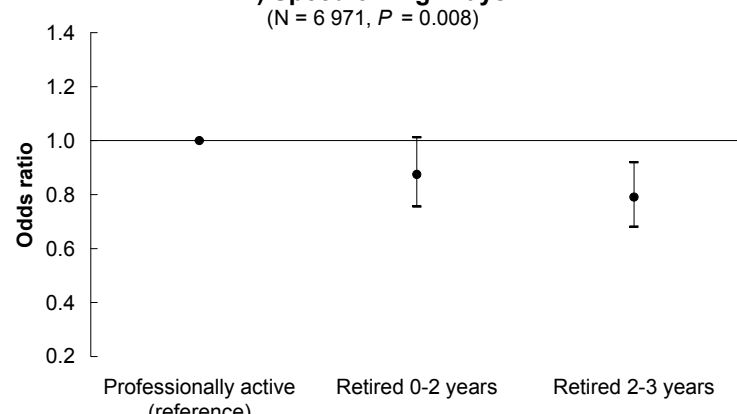

E) Sleepy driving

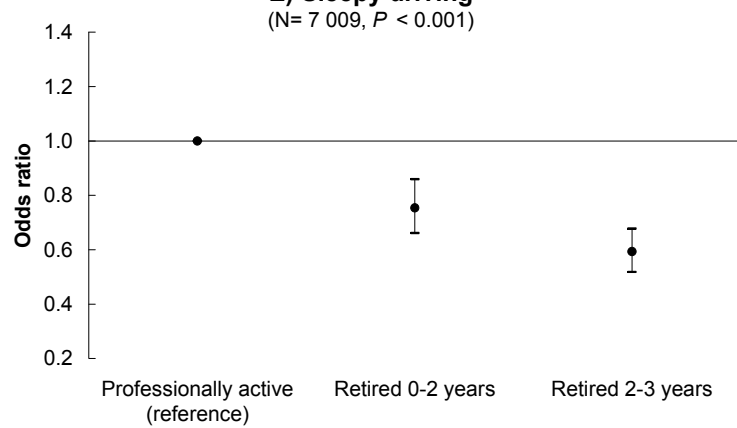

G) Attitudes toward relaxing existing regulations

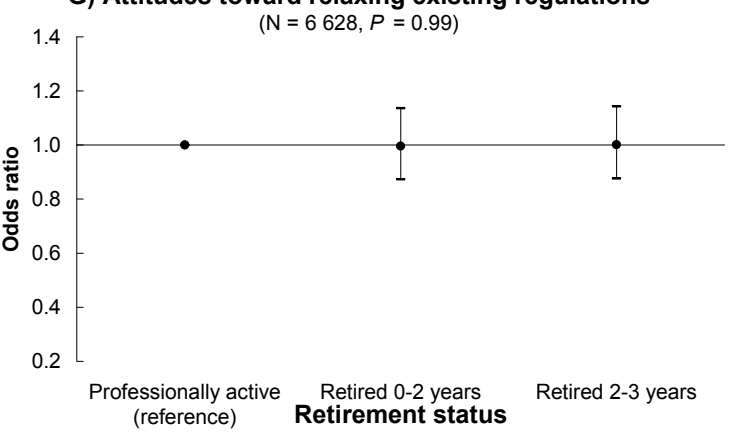

B) Speed on rural roads

$(\mathrm{N}=7002, P<0.001)$

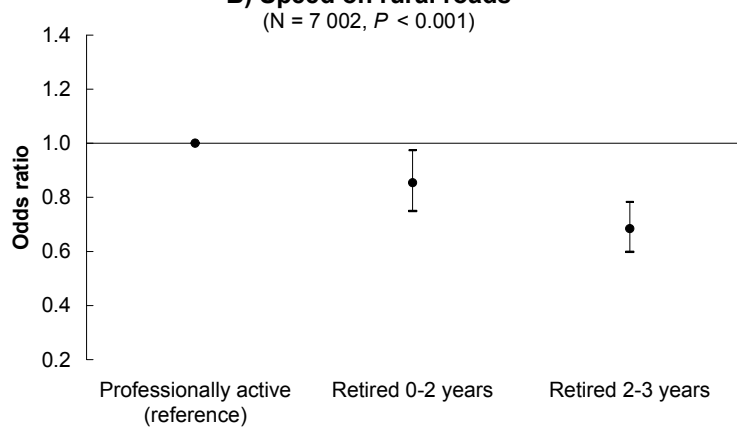

D) Driving while intoxicated

$(\mathrm{N}=6989, P=0.20)$

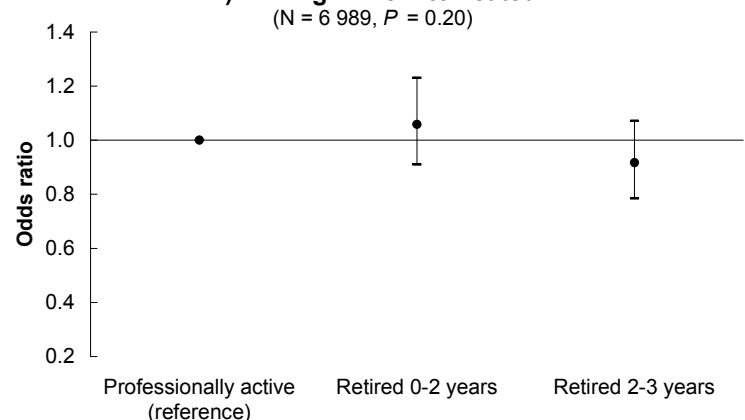

F) Phoning while driving

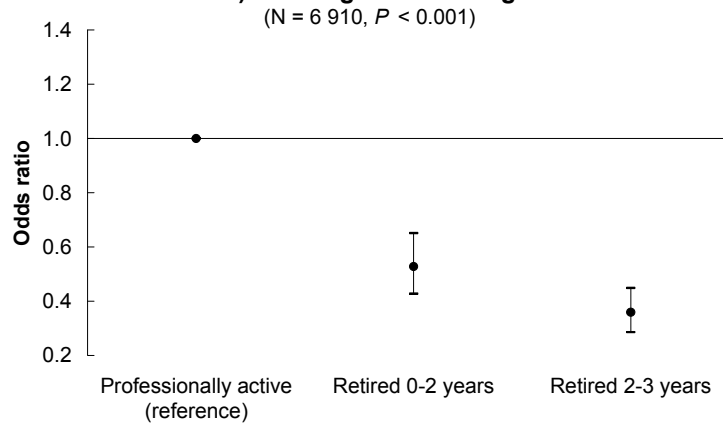

H) Attitudes toward increased traffic enforcement

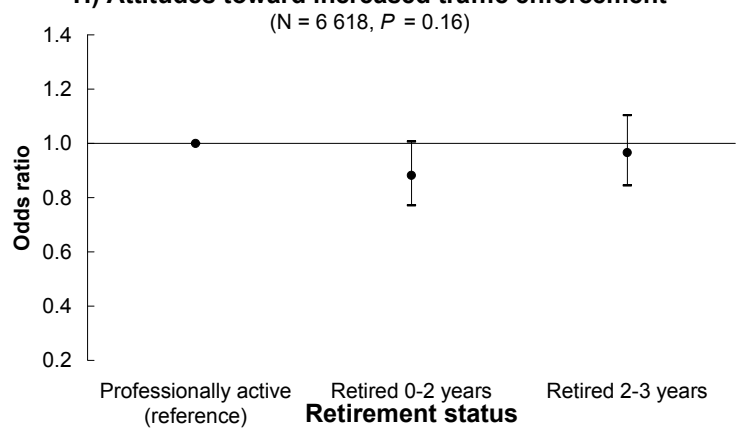

Figure 1. Odds ratios (adjusted for age, gender, marital status, professional categories, alcohol intake, road mobility, and type of vehicle driven in 2001 ) and their $95 \%$ confidence intervals for risky driving behavior and negative attitudes towards road safety as a function of time since retirement in the GAZEL cohort in 2001. [professionally active (reference) = professionally active at the date of response to the questionnaire in 2001, retired $0-2$ years $=$ retired less than 2 years before the questionnaire, retired 2-3 years = retired 2 to 3 years before the questionnaire]

while driving decreased shortly after retirement, whereas risky speedy driving decreased more slowly over time. Retirement from work had no significant effect on driving while intoxicated and attitudes towards road traffic safety.
Most studies focusing on the relationship between work and road behavior included professional drivers $(2,3,25)$, who are not representative of the general population as far as driving is concerned $(2,10$, $11,25)$. Our present study prospectively assessed 
behavioral changes after normal retirement among a large cohort of participants of diverse trades and thus highlighted how any professional activity can affect road behavior.

The decrease in sleepy driving, observed in the study population between 2001 and 2004, was likely to be facilitated by retirement during this period. The decreased likelihood of sleepy driving among those who retired is consistent with the findings of previous studies showing that job stress is associated with a poor quality of sleep (26) and that retirement provides additional time for night sleep and consequently decreases daytime napping (27). Likewise, the decrease in phone use while driving observed in the study population between 2001 and 2004 was facilitated by retirement, most likely because of the interruption of cell phone use for work purposes, which represents a large part of cell phone use during driving (28). Sleepiness and cell phone use among drivers are increasingly recognized as important factors contributing to the burden of traffic-related morbidity and mortality $(29,30)$, and our findings clearly show that professional activity partially accounts for their prevalence.

The likelihood of sleepy driving and risky phone use while driving diminished soon after retirement, while the likelihood of speedy driving remained high and decreased more slowly over time. These findings may indicate that speedy driving was, on the whole, less related to work constraints than sleepy driving and phone use while driving, as confirmed by previous data showing that speeding does not usually decrease in periods when work constraints are diminished (during weekends, leisure time, and summer holidays) (8). This delayed decrease in speeding among the retired participants may indicate a progressive change in lifestyle (31, 32 ), rather than a direct consequence of work discontinuation. As the time lapse between the two questionnaires was 3 years, this inertia (or tendency to resist change) of risky speeding may explain the absence of immediate significant changes in risky speeding after retirement between 2001 and 2004. Moreover, because the likelihood of risky speeding decreased significantly during the same period among all of the participants, it is also possible that excessive speed decreased similarly among both the retired and professionally active participants and therefore resulted in a decrease in the magnitude of change, thus lowering the statistical power of the comparison between the groups. Indeed, speed control efficiency dramatically improved during the 2002-2004 period in France, with the widespread use of binocular laser and automatic speed radars, which were partly responsible for a $145 \%$ increase in speeding tickets (8). Major changes in road behavior were concomitantly observed in France, with significant reductions in observed excessive speed, mean driving speed, and road casualties (8).
Driving while intoxicated and attitudes towards road traffic safety were not influenced by retirement. This finding suggests that these variables were independent of work-related factors. Driving while intoxicated is a complex and multifactorial problem that is not only related to compliance with traffic regulations, but also to alcohol abuse and dependence, cultural background, psychological issues, and attitudes towards driving while intoxicated (33-35). For instance, one study found that, among 224 trauma patients with a positive blood alcohol content at admission, $40 \%$ had a current alcohol dependence diagnosis, and $12 \%$ were both alcohol- and drugdependent (33). As the likelihood of this high-risk road behavior increased between 2001 and 2004 in the study population, further investigation of its determinants is a crucial issue for public health.

Findings from a previous study using the data from the same cohort participants showed that support for relaxing existing regulations decreased significantly, while support for increased enforcement waned slightly between 2001 and 2004 (23). According to the theory of planned behavior (36), attitudes towards road safety are significant predictors of road behavior (22), but results from both analyses showed that retirement had no influence on their changes over time. One study found that older drivers had higher levels of normative motivation to comply with traffic laws than younger drivers did (18). This finding indicates that age played a major role in shaping attitudes towards road traffic safety. On the whole, as the study population aged, it is likely that the participants changed their attitudes towards road traffic safety in a similar way, independently of their retirement status.

Self-reports may underestimate behavior, especially when forbidden or socially unacceptable behavior is concerned (37). There are elements, however, pointing to a fair reliability of self-reports on behavior and attitudes in our survey. First, significant trends between the risk of road traffic accidents and self-reported well-known behavior were found in the GAZEL cohort (speeding, driving while intoxicated, sleepy driving, and phone use while driving) $(22,38)$. Second, we observed a fair consistency between responses to the same questions in 2001 and in 2004, as shown by weighted kappa coefficients between behavioral self-reports ( 0.45 for sleepy driving, 0.40 for phone use while driving, and 0.51 for driving while intoxicated) and by intraclass correlations between reported speeds ( 0.49 for built-up areas, 0.42 for rural roads, and 0.61 for highways).

Our study sample is not representative of all French drivers, but its large size and the inclusion of diverse trades and socioeconomic groups throughout France represent an exceptional advantage for the assessment of road behavior in even larger samples. Although the conditions of retirement in our study differed significantly 
from those of the French population, as the participants retired at a relatively young age and did not suffer from substantial financial loss, because of company-funded retirement pensions (21), this situation allowed us to study the influence of work discontinuation on driving behavior independently of any financial or age-related health issues. Nevertheless, care must be taken before these results are generalized, as the participants were specific in terms of age and health.

Overall, our results suggest that normal retirement positively influences road behavior, with the exception of driving while intoxicated. While the reduction in excessive speed may also be attributed to other factors, such as increased traffic law enforcement, the observed discontinuation of sleepy driving and phone use while driving between 2001 and 2004 was clearly facilitated by retirement. The study of behavioral changes after retirement in a large cohort of road users represents a remarkable opportunity to identify work-related determinants of road traffic accidents, and our results suggest that further monitoring and the prevention of sleepy driving and phone use while driving among workers are of interest to help reduce the burden of road accidents.

\section{Acknowledgments}

This work was funded by Electricité de France-Gaz de France (EDF-GDF) and the Institut National de la Santé et de la Recherche Médicale (INSERM). The funding bodies had no input to the study design, the collection, analysis and interpretation of the data, or the decision to submit the paper for publication.

We would like to thank all of those who supported this work, in particular the participants of the GAZEL cohort and the staff of INSERM.

\section{References}

1. Petridou E, Moustaki M. Human factors in the causation of road traffic crashes. Eur J Epidemiol. 2000;16(9):819-26.

2. Salminen S. Traffic accidents during work and work commuting. Int J Ind Ergon. 2000;26:75-85.

3. Caird JK, Kline TJ. The relationship between organization and individual variables to on-the-job driver accidents and accident-free kilometers. Ergonomics. 2004;47(15):1598-613.

4. Wills AR, Watson B, Biggs HC. Comparing safety climate factors as predictors of work-related driving behavior. J Safety Res. 2006;37(4):375-83.

5. Harrison JE, Mandryk JA, Frommer MS. Work-related road fatalities in Australia, 1982-1984. Accid Anal Prev. 1993;25(4):443-51.

6. Charbotel B, Chiron M, Martin JL, Bergeret A. Work-related road accidents in France. Eur J Epidemiol. 2001;17(8):773-
8.

7. National Highway Traffic Safety Administration. Traffic safety facts 2001: a compilation of motor vehicle crash data from the Fatality Analysis Reporting System and the General Estimates System. Washington (DC): National Center for Statistics and Analysis; 2002.

8. Observatoire National Interministériel de Sécurité Routière (ONISR). La sécurité routière en France: bilan de l'année 2004 [Road safety in France: report 2004]. Paris: La documentation française; 2005.

9. Carton B, Mereau P, Meric M, Puzin P. Problématique relative aux accidents de la circulation des salaries en mission et lors de trajets domicile-travail [Factors related to traffic accidents of employees while travelling during work and home to work ]. Vandoeuvre les Nancy (France): Institut National de Recherche et de Sécurité (INRS); 1996. INRS report, 147.

10. Lyman S, Braver ER. Occupant deaths in large truck crashes in the United States: 25 years of experience. Accid Anal Prev. 2003;35(5):731-9.

11. BOMEL Limited. Safety culture and work-related road accidents. London: Department of Transport; 2004. Road safety research report, 51.

12. Lenguerrand E, Martin JL, Chiron M, Lagarde E, Laumon B. Road crash involvement and professional status: a prospective study using the French Gazel cohort. Accid Anal Prev. 2008;40(1):126-36.

13. Chiron M, Bernard M, Lafont S, Lagarde E. Tiring job and work related injury road crashes in the GAZEL cohort. Accid Anal Prev. 2008;40(3):1096-104.

14. Howard JH, Rechnitzer PA, Cunningham DA, Donner AP, Change in type A behavior a year after retirement. Gerontologist. 1986;26(6):643-9.

15. Nabi H, Consoli SM, Chastang JF, Chiron M, Lafont S, Lagarde E. Type A behavior pattern, risky driving behaviors, and serious road traffic accidents: a prospective study of the GAZEL cohort. Am J Epidemiol. 2005;161(9):864-70.

16. De Raedt R, Ponjaert-Kristoffersen I. The relationship between cognitive/neuropsychological factors and car driving performance in older adults. J Am Geriatr Soc. 2000;48(12):16648.

17. Raitanen T, Törmäkangas $T$, Mollenkopf $H$, Marcellini $F$. Why do older drivers reduce driving?: findings from three European countries. Trans Res Part F: Traffic Psychol Behav. 2003;6(2):81-95.

18. Yagil D. Gender and age-related differences in attitudes toward traffic laws and traffic violations. Trans Res Part F: Traffic Psychol Behav. 1998;1(2):123-35.

19. Aberg L, Sànches F, Valentin A. Current research and national experiences: improving road safety by attitude modification. Paris: Organisation for Economic Co-operation and Development (OECD); 1994.

20. Rosenkoetter MM, Garris JM. Psychosocial changes following retirement. J Adv Nurs. 1998;27(5):966-76.

21. Goldberg M, Leclerc A, Bonenfant S, Chastang JF, Schmaus A, Kaniewski N, et al. Cohort profile: the GAZEL Cohort Study. Int J Epidemiol. 2007;36(1):32-9.

22. Nabi H, Rachid Salmi L, Lafont S, Chiron M, Zins M, Lagarde E. Attitudes associated with behavioral predictors of serious road traffic crashes: results from the GAZEL cohort. Inj Prev. 2007;13(1):26-31.

23. Constant A, Salmi LR, Lafont S, Chiron M, Lagarde E. The recent dramatic decline in road mortality in France: how drivers' attitudes towards road traffic safety changed between 2001 and 2004 in the GAZEL cohort. Health Educ Res. 2007 Dec 6. 
[Epub ahead of print]

24. SAS for Windows. 9.1.3 ed. Cary (NC): SAS Institute Inc; 2002.

25. Adams-Guppy JR, Guppy A. Speeding in relation to perceptions of risk, utility and driving style by British company car drivers. Ergonomics. 1995;38(12):2525-35.

26. Knudsen HK, Ducharme LJ, Roman PM. Job stress and poor sleep quality: data from an American sample of full-time workers. Soc Sci Med. 2007;64(10):1997-2007.

27. Webb WB, Aber WR. Relationships between sleep and retirement-nonretirement status. Int J Aging Hum Dev. 1984;20(1):13-9.

28. Brusque C, Alauzet A. Analysis of the individual factors affecting mobile phone use while driving in France: socio-demographic characteristics, car and phone use in professional and private contexts. Accid Anal Prev. 2008;40(1):35-44.

29. Laberge-Nadeau C, Maag U, Bellavance F, Lapierre SD, Desjardins D, Messier S, et al. Wireless telephones and the risk of road crashes. Accid Anal Prev. 2003;35(5):649-60.

30. Morrow PC, Crum MR. Antecedents of fatigue, close calls, and crashes among commercial motor-vehicle drivers. J Safety Res. 2004;35(1):59-69.

31. Perreira KM, Sloan FA. Life events and alcohol consumption among mature adults: a longitudinal analysis. J Stud Alcohol. 2001;62(4):501-8.

32. Chung S, Popkin BM, Domino ME, Stearns SC. Effect of retirement on eating out and weight change: an analysis of gender differences. Obesity (Silver Spring). 2007;15(4):105360 .

33. Soderstrom CA, Ballesteros MF, Dischinger PC, Kerns TJ, Flint RD, Smith GS. Alcohol/drug abuse, driving convictions, and risk-taking dispositions among trauma center patients. Accid Anal Prev. 2001;33(6):771-82.

34. Baum S. Drink driving as a social problem: comparing the attitudes and knowledge of drink driving offenders and the general community. Accid Anal Prev. 2000;32(5):689-94.

35. Yang MJ, Yang MS, Kawachi I. Work experience and drinking behavior: alienation, occupational status, workplace drinking subculture and problem drinking. Public Health. 2001;115(4):265-71.

36. Ajzen I. Attitudes, personality and behavior. Buckingham (Great Britain): Open Press University; 1988.

37. Paulhus DL. Socially desirable responding: some new solutions to old problems. In: Buss DM, Cantor N, editors. Personality psychology: recent trends and emerging directions. New York (NY): Springer-Verlag; 1989. p 201-9.

38. Nabi H, Gueguen A, Chiron M, Lafont S, Zins M, Lagarde E. Awareness of driving while sleepy and road traffic accidents: prospective study in GAZEL cohort. BMJ. 2006;333(7558):75.

Received for publication: 13 March 2008 